\title{
Characteristics of product complementary feeding with fortified fish protein hydrolysate (FPH)
}

\author{
${ }^{1}$ Nuryanto, ${ }^{2, *}$ Chasanah, E., ${ }^{1}$ Afifah, D.N., ${ }^{2}$ Fawzya, Y.N., ${ }^{2}$ Suryaningrum, T.D., \\ ${ }^{2}$ Martosuyono, P., ${ }^{1}$ Putri, Y.I., ${ }^{1}$ Rossalia, A., ${ }^{1}$ Asmak, N. and ${ }^{1}$ Ihsani, K. \\ ${ }^{I}$ Department of Nutrition Science, Faculty of Medicine, Diponegoro University; Jl. Prof. Soedarto \\ SH, Tembalang Semarang Indonesia \\ ${ }^{2}$ Research and Development Center for Marine and Fisheries Product Processing and Biotechnology, \\ Jl. KS Tubun, Petamburan 6, Slipi, jakarta, Indonesia
}

\begin{abstract}
Article history:
Received: 16 November 2020 Received in revised form: 16 January 2021

Accepted: 20 March 2021

Available Online: 16 January 2022
\end{abstract}

\section{Keywords:}

Fortification,

Complementary Feeding, Fish Protein Hydrolysate (FPH),

Sensory,

Protein absorption in vivo, In vitro

\section{DOI:}

https://doi.org/10.26656/fr.2017.6(1).665

\begin{abstract}
Malnutrition is still a major problem in Indonesia, particularly stunting and acute malnutrition due to protein deficiency. In contrast, Indonesia is rich in protein sources such as fish but they are poorly utilized. Biologically processed fish protein hydrolysate (FPH) has proven to be highly nutritious and digestible. Our preliminary study in developing the High Protein Complementary Food (HPCF) formula for infant enriched with FPH, showed that of 17 formulas, 3 formulas was the best. This study was aimed to analyzing sensory analysis using the hedonic test, physical analysis and absorption protein. The result shows that the hedonic test of FPH-enriched HPCF infant food revealed that the product was acceptable in term of colour, aroma and texture. In comparison to the commercial product, FPH-enriched instant HPCF infant product had higher bulk density. The highest Water Absorption Index (WAI) was F1-C, the highest Water Solubility Index (WSI) was F1-P, and the lowest rehydration was F2-P. Compared to commercial products, the instant FPH-enriched HPCF baby porridge has a bulk density that is greater than that of commercial products. The highest Water Absorption Index (WAI) was F1-C, the highest Water Solubility Index (WSI) was F1-P and the lowest time for Rehydration was at F2-P. HPCF enriched with FPH showed the best protein absorption significantly in the $\mathrm{P} 2$ treatment group.
\end{abstract}

\section{Introduction}

Malnutrition is still a major problem in Indonesia, especially stunting and wasting which are still commonly found in Indonesian children. UNICEF 2012 reported that 1 out of 3 children in Indonesia suffered from stunting due to protein deficiency. Based on the data from the Indonesian Ministry of Health, a total of $37.2 \%$ of Indonesian children were classified as stunted in 2013 (Balitbang Kemenkes RI, 2013), an increased from the previous years where it was $35.6 \%$ and $36.8 \%$ in 2010 and 2007 respectively.

Stunting is defined as growth failure in infants or children where their body height is lower than the standard for their age (Bloem et al., 2013). Stunting not only causes loss of linear growth but also affects the children in the short and long term. Short-term impacts include delayed cognitive development (de Onis and Branca, 2016) and poor school performance. These children will then grow into adults with low work productivity and income, as well as increased risks of noncommunicable diseases such as diabetes and coronary heart disease (World Health Organization, 2010). On a nationwide level, this results in sub-optimal human resource capacity with a mediocre quality of life, which is a considerable loss for a developing country like Indonesia.

Factors that contribute to stunting are low birth weight, exclusive breastfeeding, infectious diseases, parental height, maternal education, and family income. Complementary feeding, particularly the nutritional quality of complementary food, is another vital factor for stunting (Paudel et al., 2012). To improve the quality of human resources, the government of Indonesia has a program called The First 1000 Days of Life Program. The First 1000 Days of Life Program, referring to the period starting from conception to the child's second birthday. At the age of 6 to 24 months, infants need to be given complementary feeding. If the complementary 
foods received in this period cannot fulfil their nutritional requirements, they will suffer from impaired growth which will lead to stunting (Dewey and AduAfarwuah, 2008). Complimentary food should be given when children are 6 months old. Feeding before that age will cause various complications for the child as their immune system has not fully developed and making them vulnerable to possible allergic reactions.

Complementary feeding should be provided along with breastmilk. World Health Organization (WHO) defined complementary feeding as a process starting when breastmilk alone is no longer sufficient to meet the nutritional requirements of infants. Complementary feeding is especially important because breastmilk is becoming inadequate in supplying the infant needs both nutritionally and energy, for example for 3-5 months old infant, they need $550 \mathrm{kcal} /$ day (World Health Organization, 2010).

The most popular type of complementary feeding is instant infant food such as porridge or biscuits (Aboud et al., 2009). Instant food is favoured over homemade food due to its practicality. The nutritional content of instant infant food products is carefully regulated in Indonesia with the national standard SNI 01-7111.1/2 the year 2005 and the Badan Pengawasan Obat dan Makanan (Badan Pengawas Obat dan Makanan, 2021). The regulations state that instant infant porridge must be easily digestible, contains high in energy, protein, fat, vitamins, and minerals (Aboud et al., 2009), organoleptically acceptable, and easy to serve.

Instant infant porridge is commonly made of rice flour, skimmed milk, powdered sugar, and vegetable oil. In order to increase the nutritional content, those ingredients can be substituted with other food), for instance by locally available food that is rich in protein. Protein is an important macronutrient that contributes to childhood growth and development, serves as a source of energy, and performs many bodily functions such as neurotransmitters. Protein is made up of amino acids. Five of those are essential amino acids that are frequently deficient in children's diet are: namely lysine, methionine, threonine, tryptophan, and cysteine. Protein can be obtained from animal or plant sources, but a combination of both sources will nutritionally complement each other.

Legume is an example of plant food that is widely known as a good source of protein and vitamins. Legumes are typically rich in lysine, leucine, and isoleucine, but have low quantities of methionine and cysteine (Shevkani, Singh, Kaur and Rana, 2015). Mung beans, in particular, are protein-rich legumes, containing $20.97 \%-31.32 \%$ of protein which is higher than other beans like soybeans or red beans. Mung beans have a high content of leucine, lysine, phenylalanine, and tyrosine; but are poor in sulfuric amino acids like methionine and cysteine (Anwar et al., 2007, Ping et al., 2015; Shevkani et al., 2015). However, this gap can be closed by combining it with fish products.

As a source of animal protein, fish contains essential amino acids such as lysine, methionine, cystine, threonine, and tryptophan. Fish is an excellent source of lysine the limiting amino acid in cereals and legumes (Istiqomah et al., 2018). Fish boasts high protein content (15-24\%), all the essential amino acids, high digestibility (95\%), and omega-3 fatty acid content which is beneficial for children's health and growth. In this study, we used kuniran fish (Upeneus moluccensis). This demersal fish was chosen because it is an abundant, and economic value. Our previous research on the production of fish protein hydrolysate in a scale-up study $(100 \mathrm{~kg}$ fish) used the fish from Cirebon fishmarket having a moisture content of $77.46 \pm 0.48 \%$, protein (DB) of $92.24 \pm 2.66 \%$, fat (DB) $1.86 \pm 0.18$, and ash (DB) $7.23 \pm 0.53 \%$ (Martosuyono et al., 2019)

Kuniran fish (Upeneus moluccensis) was processed into a fish protein hydrolysate (FPH) using enzymatic reactions to attain simple, short-chained proteins for easier digestion. Having better functional properties than fish flour, including high solubility. FPH has a wide application in various food products (Nurhayati et al., 2007). Lab-scale production of FPH has been conducted from various fish, resulting in that FPH can be produced from various fish (Chasanah et al., 2019). In this study, we used FPH to formulate an instant porridge called High Protein Complementary Food (HPCF) formula for an infant. The HPCF formula used mung bean, and skimmed milk in addition to FPH as a highly nutritious complementary food that promotes the growth and development of infants aged 6 months and above. Our previous study showed that of 17 formulas, 3 have been chosen to have a moisture content of $7.14-7.34 \%$, the protein content of $18.72-19.38 \%$. ash $2.95-3.10 \%$ and fat content of $5.44-5.82 \%$ The 3 formulas meet the standard requirements of iron and zinc according to SNI 01-7111.4-2005, but not for Ca (Putri et al., 2020). This study was intended to evaluate sensory and physical properties of the 3 best formula developed in the previous study protein absorption by the inverted gut pouch method was used to see how long and how much protein the Sprague Dawley rats could accept.

\section{Materials and methods}

\subsection{Materials}

The ingredients for making instant complementary 
food were protein sources from skim milk, FPH powder, and mung bean flour, fat sources from vegetable oils and carbohydrates from red bean flour. Additional ingredients include powdered sugar and water. The composition of the complementary feeding formula per $100 \mathrm{~g}$ is shown in Table 1. Formula 1 (F1) contains (18\% skim milk, 7.6\% FPH, 37.8\% mung bean flour), Formula 2 (F2) contains (15\% skim milk, FPH 7.6\%, mung bean flour 45.6\%), Formula 3 (F3) contains (18\% skim milk, FPH 6.2\%, mung bean flour $45.6 \%$ ) and F4 is a commercial formula. Aquades, Warm water (for brewing). Reagents for absorption of intestinal pouch protein inverted method $(\mathrm{NaCl}$ and serosa).

\subsection{Organoleptic test}

Acceptability and preferences towards the food product were estimated with the hedonic approach where the target consumer group was asked to express their degree of liking towards the food product attributes. The first step for the organoleptic test was to pour instant complementary feeding into a container and add warm water with a 1:3 ratio. Afterwards, the panellists have assessed the appearance, smell, and texture of the three formulas. The scoring was done using a 5-point hedonic scale. 1 was for dislike very much, 2 for dislikes, 3 for neutral, 4 for likes, and 5 for likes very much (Lim, 2011). The organoleptic test was used hedonic test which was done by fifteen trained panellists

\subsection{Physical properties analysis}

\subsubsection{Color analysis}

Color analysis was carried out using the colorFlex EZ spectrophotometer. The color test was carried out using Hunter $\mathrm{L}^{*}$ color system (the contribution of black or white varies between 0 and 100), $\mathrm{a}^{*}$ (redness $(+)$ and green $(-), b^{*}$ (yellowish $(+)$ and bluish $(-)$. The first step was calibrated the chromameter used white standard from the instrument. The results of the whiteness analysis are the values of $\mathrm{L}^{*}, \mathrm{a}^{*}, \mathrm{~b}^{*}$ and WI (whiteness index), YI (Yellowness index). The measurement of the total degree of color used a white base as a standard.

\subsubsection{Bulk density}

Bulk density measurements were carried out using a measuring cup. The measured material was weighed as much as $10 \mathrm{~g}$, then put into a $100 \mathrm{~mL}$ measuring cup. The bottom of the measuring cup was tapped several times to obtain a constant volume. The total bulk density was calculated with the following equation.

$$
\text { Bulk density }(\mathrm{g} / \mathrm{mL})=\frac{\text { Weight }(\mathrm{g})}{\text { Volume }(\mathrm{mL})}
$$

2.3.3 Water absorption index and water solubility index

The centrifugation method was used in this research. One gram of flour sample was put into a centrifuge tube whose previously weighed. $10 \mathrm{~mL}$ of distilled water was added to the centrifuge tube and stirred with a vortex until all the ingredients were evenly dispersed. Afterwards, the tube was centrifuged at $200 \mathrm{rpm}$ at room temperature for 15 mins. The supernatant obtained was poured into another container, while the centrifuge tube and the residue were heated in an oven. The tube is placed at an angle $\left(25^{\circ}\right)$ and the oven is set at $50^{\circ} \mathrm{C}$ for 25 mins. The tube that contains the residue was weighed to determine the weight of absorbed water.

One gram obtained supernatant was taken as a sample and was put into a weighing dish whose weight was known. Afterwards, the cup was put in the oven and was dried at $110^{\circ} \mathrm{C}$ until all the water had evaporated. The cup was cooled and weighed to determine the weight of the dry substance which contained in the supernatant. The Water Absorption Index (WAI) and Water Solubility Index (WSI) were calculated using the following equations:

WAI $(\mathrm{mL} / \mathrm{g})=\frac{\text { Post }- \text { heating weight of the tube and residue }(\mathrm{g})-\text { initial weight of the tube and sample }(\mathrm{g})}{\text { Sample weight }}$
WSI $(\mathrm{g})=\frac{\text { Post }- \text { heating weight of the tube and residue }(\mathrm{g})-\text { initial weight of the tube and sample }(\mathrm{g})}{1 \mathrm{~g}}$

\subsubsection{Brew analysis}

The brew test indicates the amount of water needed to make the slurry homogeneous and ready to serve formulas. The brewing test refers to the instructions for serving commercial infant food products as a control. $100 \mathrm{~mL}$ of warm water $\left(60^{\circ} \mathrm{C}\right)$ was added into a $24 \mathrm{~g}$ (dose per serving) sample, and then it stirred evenly to form a thick slurry solution like commercial infant food. The amount of water used to obtain the same consistency as commercial infant food porridge was the amount of water needed for its serving.

\subsubsection{Rehydration time}

The amount of warm water from the brew test that was needed for formulas serving was added into a total of $24 \mathrm{~g}$ sample, then stirred evenly until it became a thick porridge. The rehydration time was calculated when the sample when the water was added until it slurry.

\subsection{Growth}

True experimental research on SD rats with the approach of Randomized Pre-test post-test control group design was conducted to determine the effect of FPHenriched HPCF on growth. Table 1 shows the composition of the complementary feeding formula per 
Table 1. Composition of Complementary Feeding Formula per $100 \mathrm{~g}$

\begin{tabular}{lccccc}
\hline Ingredients & $\mathrm{K}$ & $\mathrm{F} 1(\mathrm{~g})$ & $\mathrm{F} 2(\mathrm{~g})$ & $\mathrm{F} 3(\mathrm{~g})$ & Commercial $(\mathrm{g})$ \\
\hline Brown rice flour & - & 21.6 & 16.8 & 15.2 & - \\
Mung bean flour & - & 37.8 & 45.6 & 45.6 & - \\
Skimmed milk flour & - & 18 & 15 & 18 & - \\
FPH Powder & - & 7.6 & 7.6 & 6.2 & - \\
Fine granulated sugar & - & 5 & 5 & 5 & - \\
Palm oil & - & 10 & 10 & 10 & - \\
Promina & - & - & - & - & 100 \\
AIN-93 G & 100 & - & - & - & - \\
\hline
\end{tabular}

$100 \mathrm{~g}$ that will be given to male SD rats.

There were four treatment groups and one control group, each group consisting of 5 male SD rats with the average body weight between groups not exceeding $10 \mathrm{~g}$. The treatment was carried out for 14 days with bodyweight measurements carried out on days $0,1,3,7$, 10 and 14 using animal scales. Table 2 shows the division of experimental rat groups and the formula given according to the treatment group. The rat's food intake was measured every day by weighing the remaining feed to determine the rat's total feed consumption for 14 days.

Table 2. Division of experimental rat group

\begin{tabular}{ccc}
\hline Rat Group & Treatment & Amount \\
\hline K & positive control & 5 tails \\
P1 & F1 $0.18 \mathrm{~g} / 50 \mathrm{gBB} /$ day & 5 tails \\
P2 & F2 $0.18 \mathrm{~g} / 50 \mathrm{gBB} /$ day & 5 tails \\
P3 & F3 $0.18 \mathrm{~g} / 50 \mathrm{gBB} /$ day & 5 tails \\
P4 & Commercial $0.18 \mathrm{~g} / 50 \mathrm{gBB} /$ day & 5 tails \\
\hline
\end{tabular}

\subsection{Evaluation of protein nutritional value}

\subsubsection{In vivo}

Evaluation of protein nutritional value used in vivo method was consists of two methods, namely the growth method and the nitrogen balance method. The measured parameters for the growth method in this research were Feed Conversion Efficiency (FCE) and Protein Efficiency Ratio (PER). FCE and PER measurement data were taken during treatment.

\subsubsection{Feed conversion efficiency}

The FCE value was determined through tests that were carried out for 14 days. FCE values were required for all groups of experimental mice. FCE calculation was done using the following formula:

$$
\text { FCE }(\%)=\frac{\text { weight gain }(g)}{\text { Amount of food that consumed }(\mathrm{g})} \times 100 \%
$$

\subsubsection{Protein efficiency ratio}

The protein efficiency ratio (PER) value was determined through tests that were carried out for 14 days, using casein as a reference protein. Calculations were performed for each rat, and the average value was calculated for each group. The PER calculation did not apply to the non-protein group of mice. PER calculation was done using the following formula:

$$
\text { PER }(\%)=\frac{\text { weight gain }(g)}{\text { Amount of protein that consumed }(\mathrm{g})} \times 100 \%
$$

\subsubsection{In vitro digestibility test}

Analysis of protein digestibility in vitro can be done by making similar conditions as digestion conditions in the human body using digestive enzymes. Protein digestibility in vitro analysis based on the decrease in protein $\mathrm{pH}$ that occurred after the hydrolysis reaction. The ingredients that used in this method are casein, instant baby porridge powder that has gone through an optimization process, $1 \mathrm{~N} \mathrm{NaOH}, 0.1 \mathrm{M}$ TCA, $\mathrm{NO}_{2} \mathrm{CO}_{3}$, folin reagent, and a mixture of enzymes (1.6 $\mathrm{mg}$ trypsin $+3.1 \mathrm{mg}$ chymotrypsin $+4 \mathrm{mg}$ pancreatin per $\mathrm{ml}$ of distilled water or phosphate buffer $\mathrm{pH}$ 8.0), 0.1 M TCA, $0.4 \mathrm{M} \mathrm{Na}_{2} \mathrm{CO}_{3}$, and $50 \%$ Folin reagent $(30 \mathrm{~mL}$ Folin + $60 \mathrm{~mL}$ aquadest). The composition of the complementary feeding formula per $100 \mathrm{~g}$ is shown in Table 1.

Each sample F1, F2, F3 was taken as much as $0.5 \mathrm{~g}$ for 2 replications. Distilled water was added $(30 \mathrm{~mL}, \mathrm{pH}$ 8 ) and stirred until homogeneous. $20 \mathrm{~mL}$ of the solution was taken for treatment, while the rest was measured for initial $\mathrm{pH}$. The treatment sample $(10 \mathrm{~mL})$ was added with $1 \mathrm{~mL}$ of enzyme solution and the remainder was used as a blank solution. The treatments and blanks were then incubated and $2 \mathrm{~mL}$ was taken while the remaining $\mathrm{pH}$ was measured after incubation. Approximately, $2 \mathrm{~mL}$ of the solution were added with TCA $(0.1 \mathrm{M}, 4 \mathrm{~mL})$ and centrifuged (3500 rpm, 10 mins). The supernatant from the centrifugation was taken $1.5 \mathrm{~mL}$ and added $\mathrm{Na}_{2} \mathrm{CO}_{3}$ $(5 \mathrm{~mL})$ and folin $(1 \mathrm{~mL})$. The solution was incubated $(20$ mins, $37^{\circ} \mathrm{C}$ and absorbance were measured using a spectrophotometer (wavelength: $578 \mathrm{~nm}$ ).

\subsection{Protein absorption}

This study used twelve Sprague Dawley (SD) weaned male rats aged 21-23 days, average bodyweight 48-52 grams with AIN-93 G ration $5 \mathrm{~g} / 50 \mathrm{~g}$ BW/day plus $0.18 \mathrm{~g} / 50 \mathrm{~g} \mathrm{BW} /$ day sonde. The reason for using the Sprague Dawley rat is because it is more sensitive to food and has physiological effects on humans (Yudi and 
Parakkasi, 2005). Weaned rats are unable to regurgitate food that has been probed (Muchtadi, 2010). Rats were divided into 4 groups, namely groups P1, P2, P3, and P4 with the treatment as shown in Table 2. They fast for 810 hrs. The male SD (Sprague Dawley) experimental animal was obtained from the Central Laboratory of Food and Nutrition Studies at Gajah Mada University, Yogyakarta. Inverted pouch bowel research method with 4 treatment groups and each group was repeated three times so that we used 12 male Sprague Dawley rats.

First, the rats were anaesthetized using ether and their stomachs were opened to expel their contents. After the small intestine (duodenum) was cut and washed with physiological saline $(0.9 \% \mathrm{NaCl})$ then it was turned over using a glass stirring rod so that the villi were outside. Then, the remaining dirt was washed with $0.9 \% \mathrm{NaCl}$. One end of the bowel bag was tied with a thread while the other end was attached to the cannula. The effective length of the intestine in the fluid-filled state was $7 \mathrm{~cm}$. The bowel sac was filled with a physiological (serous) saline solution. The bowel sac is filled with a physiological (serous) saline solution. The tube is filled with $75 \mathrm{~mL}$ of sample (mucosa). During the experiment the intestine was immersed in the sample solution and always filled with oxygen (100 bubbles/min), the temperature was $37^{\circ} \mathrm{C}$ and stirred continuously on a water bath shake. Absorption by the method of the reverse bowel bag in 30 mins, 60 mins, 90 mins, and 120 mins. Protein absorption was taken five times for $2 \mathrm{hrs}$ (mins $0,30,60,90$, and 120). The percentage of everted gut sac method protein absorption was calculated by:

$$
\% \text { absorbtion }=\frac{\sum \text { absorption }}{\sum \text { sample wich is entered in }} \times 100 \%
$$

\subsection{Statistical analysis}

The results of the hedonic test were analyzed using the Kruskal Wallis difference test. Data from the physical analysis was used as a descriptive analysis. Statistical analysis on growth includes analysis of differences in pre-test and post-test data, if the data is normal, then the paired t-test is used, while if the data is not normally distributed, then the Wilcoxon test is used. The second analysis is the analysis of differences in the effect between groups during treatment on growth, FCE, PER, and protein absorption using the one-way ANOVA test followed by the Post Hoc Bonferroni test if the data variance is the same $(p>0.05)$ and the data are normal. Variants of different data $(p<0.05)$, one-way ANOVA test followed by Tamhane's Post Hoc. The data was not normal, the test used was Kruskal Wallis followed by the Mann Whitney test. In vitro digestibility data analysis used in this study includes descriptive analysis and was attached in the form of a 2-dimensional graph.

\section{Results}

Previous research revealed that 3 formulas were chosen because of their protein content, namely F1 (CP 2), F2 ( $\mathrm{CP}$ 6), F3 (CP 15). The formula has been processed in the form of a mixture $(\mathrm{C})$ and separated each ingredient component $(\mathrm{P})$. When the formula is processed in mixed form, the product has a more brownish color, a sharp smell and a coarse texture, whereas when the formula is processed separately from each ingredient, the product has a brighter color, more acceptable odor and a softer texture. Table 3 and Table 4 show the sensory values of the powder and porridge of the developed complementary feeding products. Statistically, there was no difference in consumer acceptance of the appearance, smell and texture of the tested products in either powder or porridge form. However, the more FPH was added, the fishy odor was stronger. In this research, products with an FPH of $7.65 \%$ were accepted which are processed separately. Less milk and mung beans were used in the product to achieve sufficient protein content for complementary feeding products. For further study, product F2 was used.

Compared to the commercial product, the F2 product had a higher bulk density, which was $0.541 \pm 0.02$

Table 3. Sensory evaluation results of the powder from infant food product

\begin{tabular}{ccccccc}
\hline & F1- P & F2- P & F3- P & F1- C & F2- C & F3- C \\
\hline Appearance & 4.93 & 4.80 & 4.87 & 2.93 & 3.13 & 3.40 \\
Odour & 3.53 & 3.87 & 3.47 & 3.27 & 3.33 & 3.73 \\
Texture & 4.67 & 4.60 & 4.60 & 3.60 & 3.53 & 3.67 \\
Average & 4.38 & 4.42 & 4.31 & 3.27 & 3.33 & 3.60 \\
\hline
\end{tabular}

$\mathrm{P}=$ Ingredients processed separately, $\mathrm{C}=$ Ingredients processed as a mix

Table 4. Sensory evaluation results of the porridge from of infant food product

\begin{tabular}{ccccccc}
\hline & F1- P & F2- P & F3- P & F1- C & F2- C & F3- C \\
\hline Appearance & 4.27 & 4.27 & 3.87 & 2.53 & 3.33 & 3.37 \\
Odour & 3.47 & 3.07 & 3.00 & 3.53 & 3.20 & 4.13 \\
Texture & 3.73 & 4.10 & 3.53 & 3.07 & 3.67 & 3.80 \\
Average & 4.00 & 3.89 & 3.68 & 3.33 & 3.63 & 3.84 \\
\hline
\end{tabular}

$\mathrm{P}=$ Ingredients processed separately, $\mathrm{C}=$ Ingredients processed as a mix 
compared to $0.445 \mathrm{~g} / \mathrm{mL}$, it was indicated that the commercial complementary feeding product without FPH could have more volume with the same development as the commercial complementary feeding product without FPH products produced in this study. Meanwhile, the $\mathrm{F} 2$ product has a shorter processing time to be ready to eat compared to the commercial one, namely the development of the product's ability for a better commercial value from bulk density/kamba density, brewing test, rehydration time $104.5 \pm 0.35$; $35.98 \pm 1.60 ; 3.957 \pm 0.03 ; 0.0386 \pm 0.0007$.

Physical tests were carried out on 3 instant baby porridge products as a result of the research including the bulk density, brewing test, dehydration test and water absorption index. A product that has a small bulk density value means that the product has a lightweight but a large volume (space), while the brewing test describes the time required when amount water was added to the flour until a homogeneous dough was formed and is ready to be served. The results in Table 5 show that the FPH-enriched HPCF product from this study has a higher bulk density than commercial products.

The brew test indicates the amount of water needed to make the porridge homogeneous and ready to serve. Brew, then count the time until the porridge is ready to be served. The amount of water added was $100 \mathrm{~mL}$ with $24 \mathrm{~g}$ of powder. The water temperature used is $60-70^{\circ} \mathrm{C}$.

Rat growth was assessed based on weight measurement. Rat body weight measurements were carried out five times during the study. Feeding was based on body weight on the 7th and 14th days. Table 6 shows the average of pre and post mice's body weight based on the experimental group.
Rat growth data were normally distributed $(\mathrm{p}>0.05)$ and the results of the paired t-test showed a significant increase in growth in all experimental groups $(p<0.05)$. There was a significant difference in the growth of rats between treatment groups based on the one-way ANOVA test $(p>0.05)$ and the variance test with the value of $p=0.404$ showed the same data variance $(p>0.05)$. The results of the post hoc Bonferroni test showed that there were significant differences in the growth of rats in the $\mathrm{P} 1, \mathrm{P} 2$, and $\mathrm{P} 3$ treatment groups (p $=0.000)$. There was no significant difference $(p=0.051)$ in the treatment groups $\mathrm{P} 4$ and $\mathrm{K}$, this was evidenced by the amount of increase in growth during treatment 17.60 $\mathrm{g}(\mathrm{P} 4)$ and $14.20 \mathrm{~g}(\mathrm{~K})$ which was lower than the other treatment groups. The highest growth increase was in group P2 (37.80 g).

FCE value describes the correlation of changes in body weight of rats with the amount of feed (g) consumed during the 14 days of the experiment. The Table 7 was showed the average FCE values of rats along with the results of the one-way ANOVA test. Data were normally distributed ( $>0.05$ ) and based on the one way ANOVA test there was a significant difference in the FCE value between the treatment groups and had the same variance $p=0.556(0.556>0.05)$. The results of the post hoc Bonferroni test showed that there was a significant difference in the FCE value in the treatment group P2 (0.000) when compared to the treatment groups $\mathrm{K}$ and P4 $(\mathrm{p}=1,000), \mathrm{P} 1$ and P3 $(\mathrm{p}=0.439)$. The FCE value of the $\mathrm{P} 2$ treatment group occupies the highest position $(50.99 \%)$, as evidenced by the amount of feed consumption of the P2 treatment group and can increase the bodyweight of the treated rats compared to the amount of feed consumption of the other groups. The

Table 5. Physical properties analysis of FPH based infant food

\begin{tabular}{lccccc}
\hline Formulation & $\begin{array}{c}\text { Bulk density } \\
(\mathrm{g} / \mathrm{mL})\end{array}$ & $\begin{array}{c}\text { Brewing analysis } \\
(\mathrm{mL})\end{array}$ & $\begin{array}{c}\text { Rehydration time } \\
(\text { seconds })\end{array}$ & $\begin{array}{c}\text { Water Absorption Index } \\
(\mathrm{mL} / \mathrm{g})\end{array}$ & $\begin{array}{c}\text { Water solubility index } \\
(\mathrm{g} / \mathrm{mL})\end{array}$ \\
\hline Commercial Product & $0.445 \pm 0.00$ & $100 \pm 0.00$ & $40.44 \pm 0.04$ & - & - \\
F1-P & $0.526 \pm 0.00$ & $92 \pm 1.41$ & $37.17 \pm 0.40$ & $3.691 \pm 0.56$ & $0.0399 \pm 0.000$ \\
F2-P & $0.541 \pm 0.02$ & $104.5 \pm 0.35$ & $35.98 \pm 1.60$ & $3.957 \pm 0.03$ & $0.0386 \pm 0.0007$ \\
F3-P & $0.556 \pm 0.00$ & $93 \pm 1.41$ & $37.07 \pm 0.83$ & $3.874 \pm 0.21$ & $0.0385 \pm 0.0013$ \\
F1-C & $0.667 \pm 0.00$ & $87 \pm 1.41$ & $40.41 \pm 0.57$ & $3.998 \pm 0.04$ & $0.0367 \pm 0.0015$ \\
F2-C & $0.667 \pm 0.00$ & $82.5 \pm 0.71$ & $39.59 \pm 0.62$ & $3.607 \pm 0.56$ & $0.0303 \pm 0.0059$ \\
F3-C & $0.667 \pm 0.00$ & $83 \pm 1.41$ & $37.96 \pm 0.80$ & $3.705 \pm 0.00$ & $0.0338 \pm 0.0012$ \\
\hline
\end{tabular}

$\mathrm{P}=$ Ingredients processed separately, $\mathrm{C}=$ Ingredients processed as a mix

Table 6. Average growth of rats $(\mathrm{g})$ before and after treatment

\begin{tabular}{cccccc}
\hline Rat Group & Pre Mean \pm SD & Post Mean \pm SD & $\Delta$ & $p^{\prime}$ & $p$ \\
\hline K & $46.80 \pm 2.05$ & $61.00 \pm 3.54$ & $14.20 \pm 2.39$ & 0 & 0 \\
P1 & $47.00 \pm 3.08$ & $69.80 \pm 3.56$ & $22.80 \pm 1.92$ & 0 & \\
P2 & $51.00 \pm 2.92$ & $88.80 \pm 2.39$ & $37.80 \pm 1.48$ & 0 & \\
P3 & $48.20 \pm 4.32$ & $75.40 \pm 4.83$ & $27.20 \pm 0.83$ & 0 & \\
P4 & $47.20 \pm 1.14$ & $65.00 \pm 1.87$ & $17.60 \pm 1.52$ & 0 & \\
\hline
\end{tabular}

$p^{\prime}=$ paired t-test, $p=$ one-way ANOVA Figures 
total feed consumption of the $\mathrm{P} 2$ treatment group was 74 g.

Table 7. Mean FCE value of rats (\%) during treatment

\begin{tabular}{ccc}
\hline Rat Group & Pre Mean \pm SD & $P$ \\
\hline K & $22.53 \pm 2.87$ & \\
P1 & $38.89 \pm 4.54$ & \\
P2 & $50.99 \pm 2.06$ & 0 \\
P3 & $43.44 \pm 2.97$ & \\
P4 & $24.83 \pm 3.75$ & \\
\hline
\end{tabular}

$P=$ one way ANOVA

PER determines the effectiveness of protein by measuring the growth of experimental animals. Table 8 showed the mean FCE values of rats along with the results of the one-way ANOVA test. Data were normally distributed $(\mathrm{p}>0.05)$ and based on the one way ANOVA test there was a significant difference in the FCE value between the treatment groups and had the same variance $p=0.553(0.553>0.05)$. The results of the post hoc Bonferroni test showed that there were significant differences in the FCE values in the treatment group P2 (0.000) when compared to the treatment groups $\mathrm{K}$ and $\mathrm{P} 4$ $(\mathrm{p}=1,000), P 1$ and $\mathrm{P} 3(\mathrm{p}=0.478)$. The PER value in the $\mathrm{P} 2$ treatment group occupies the highest position $(2.56 \%)$.

Table 8. Average per rat value (\%) during treatment

\begin{tabular}{ccc}
\hline Rat Group & Pre Mean \pm SD & $P$ \\
\hline K & $1.13 \pm 0.14$ & \\
P1 & $1.95 \pm 0.23$ & \\
P2 & $2.56 \pm 0.10$ & 0.000 \\
P3 & $2.18 \pm 0.15$ & \\
P4 & $1.26 \pm 0.19$ & \\
\hline$P=$ one way ANOVA
\end{tabular}

In vitro digestibility test was carried out on the instant complementary food formula, commercial instant complementary food and FPH. Figure 1 shows the percentage protein digestibility value of the sample. The commercial instant complementary food product that was used for this research was instant mushroom chicken porridge with the brand "Promina" which contains rice, sugar, skim milk, coconut oil, and chicken and mushroom powder as a protein source. The highest protein digestibility was FPH (93.61\%). The instant complementary food formula with the highest protein digestibility was the F2 formula $(90.91 \%)$. The instant complementary food and FPH formulas had a higher protein digestibility than Commercial instant complementary food $(46.3 \%)$.

Lack of protein intake causes impaired absorption and nutrition transportation so that the consumed food cannot increase muscle mass. Protein digestibility was reported to increase with the increasing variety of food ingredients added to the food, it will increase the amount of amino acids absorbed by the body (Suliantari, 1994). Absorption mean were normally distributed $(p>0.05)$ and there was a significant difference in protein absorption at the 30,60, 90 and 120-minute treatments. The post hoc Tamhane test results showed that there was no significant difference in protein absorption values in the P1 treatment group $(\mathrm{p}=0.946), \mathrm{P} 2(\mathrm{p}=0.985)$, and P3 (0.979) when compared to the $\mathrm{P} 4$ group at minute 0 . The results of the post hoc Bonferroni test showed that there was a significant difference in the value of protein absorption in the treatment groups $\mathrm{P} 1(\mathrm{p}=0.000), \mathrm{P} 2(\mathrm{p}$ $=0.000)$, and $\mathrm{P} 3(0.000)$ when compared to the $\mathrm{P} 4$ group at $30,60,90$, and 30 mins. 120 . This means that $\mathrm{P} 1, \mathrm{P} 2$, and P3 have better absorption compared to P4. The highest absorption value was in the 60th minute with an average value of $17.92 \%(\mathrm{P} 2)$.

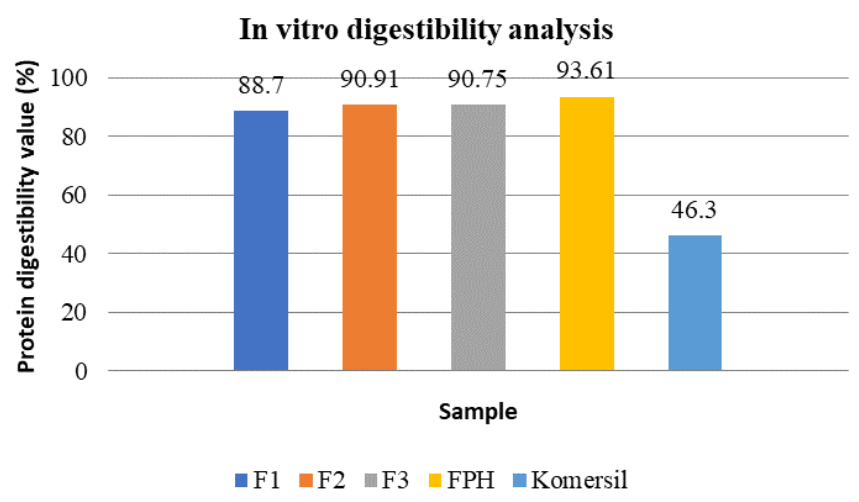

Figure 1. Digestibility analysis in vitro

These three instant complementary food formulas as a companion to breast milk seem to be superior to the commercial formula (P4).

Figure 2 shows the percentage of protein absorption by time of 4 treated groups of rats. The highest average absorption was obtained at 60 mins for all intervention groups of rats. The highest absorption was found in the rat group (P2) (the best formula), followed by P3 (formula 3), and P1 (formula 1). This difference in results is thought to be due to the role of FPH in the

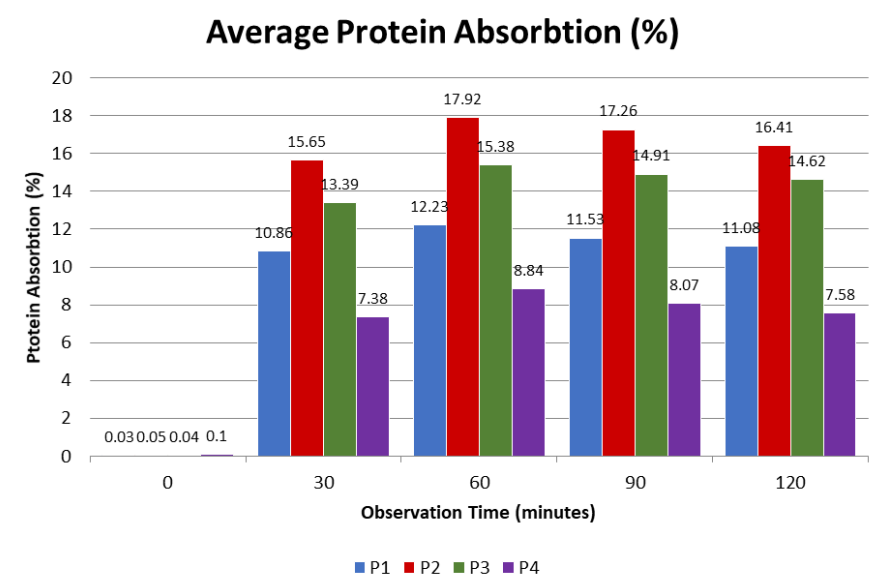

Figure 2. Percentage of protein absorption by time of 4 treated groups of rats 
developed formula, the role of FPH shown in the 3 developed formulas was very positive in improving protein absorption in the intestine.

\section{Discussion}

An acceptance test needs to be assessed on the food product. The assessment method for food or beverage products is traditionally carried out by one or two trained panellist who will provide a product quality score, namely an assessment of appearance, taste and texture based on predetermined values (Singh-ackbarali and Maharaj, 2014). The first thing that will be judged in the organoleptic test in the product is color, if the product has an unattractive color even though the taste, aroma and texture are quite good, consumers will consider taking it. Instant baby porridge formulation with fish protein hydrolysate consists of a mixture and separated each ingredient component. The mixed formula has a more brownish color, sharp aroma and coarse texture, whereas when the formula is separated by each ingredient, the product has a brighter color, more acceptable aroma and soft texture. The brown color that occurs in the mixed formula, possibly influenced by the raw material, namely mung bean flour which has undergone cooking and drying with a drum dryer to produce flour with a slightly brownish color. This brownish color is called the Maillard reaction. This browning reaction occurs non-enzymatically, namely carbohydrates (which consist of simple sugars) react with amino acids when heated (Hoseney, 1984; Liang et al., 2018).

Aromas associated with food products are sensed by the olfactory receptors present in the nasal epithelium. Therefore, to detect a scent or odor, volatile molecules must be transferred to the nasal cavity. These compounds then move in the nose during inhalation or exhalation or during eating through the back of the throat (Sharif et al., 2017). The drying process on the raw materials, namely brown rice flour and green beans, causes a browning reaction and changes in the aroma. The drying process with a drum dryer at a temperature of $70^{\circ} \mathrm{C}$ causes the enhance of the aroma. The aroma produced from volatile components released from food due to evaporation in the drying process (Hoseney, 1984; Wongpornchai et al., 2004). The more FPH is added, the fishier smell was detected, its due to the interaction of trimethylamine oxide with the double bonds of unsaturated fats to produce trimethylamine. Trimethylamine oxide is naturally found in fish muscles. In the early stages, the rate of decomposition of macromolecular compounds is still low, so the TMA content is still low. However, at the end of the biochemical process of fish meat, compounds that cause an unpleasant fishy odor such as trimethylamine and ammonia produced are quite high due to faster protein decomposition (Farahita et al., 2012). The fat hydrolysis process also produces components that can cause a fishy odor in fish meat. In the fat hydrolysis reaction, fat is converted into free fatty acids (FFA) and glycerol. The formation of free fatty acids does not affect the nutritional value of fish, but the value of free fatty acids can be used to determine the level of rancidity of fish (Aubourg, 2001).

The texture is perceived by a combination of senses, such as touch, taste, sight and hearing. This is one of the most important features of food. The texture is a prerequisite for the acceptance of various foodstuffs, such as the tenderness of the meat and the softness of the dough. This includes consistency, viscosity, friability, elasticity and the size and shape of the particles in food (Sharif et al., 2017). In the separate formula, a soft texture is obtained, while the mixed formula has a slightly rough texture.

The bulk density in powdered food ranged from $0.445-0.667 \mathrm{~g} / \mathrm{mL}$ so that the three formulations met the requirements (Gilang et al., 2013). High bulk density indicates that the product is more compact (nonvoluminous) and denser in nutrients, which is also high due to the density of particles that occupy space at a certain volume. High bulk density food is needed for babies so they do not get full quickly and nutritional intake is met (Arifianti et al., 2012; Gilang et al., 2013).

The brew test is an illustration of the rehydration ratio between the amount of water added and the amount of food ingredients in each serving. The amount of water added should not be too much because it can cause the child to feel full quickly while not having enough energy. The starch content is thought to affect the amount of water for rehydrating the instant baby porridge formula. When the starch suspension in water is heated, the starch will undergo a gelatinization process. The water that was previously outside the granules and was free to move is now in the starch grains and cannot move freely anymore because it has formed an irreversible matrix (cannot return to its original shape). When dried, the water component evaporates leaving the matrix so that it is porous and can easily reabsorb water. The existence of empty spaces between the baby porridge powder particles will make it easier for water to enter the product. The more space or product porosity, the more water can enter the product.

One of the instant food requirements is that the food is ready to be served in a short time. The instant baby porridge rehydration time is calculated by dissolving the baby porridge with the specified amount of water, then counting the time until the porridge is ready to be served. 
Table 3 shows the average value of the rehydration time of the separated powdered baby porridge formula $(\mathrm{P})$ in the range of $35.98-37.17 \mathrm{~s}$, the mixed baby porridge powder $(\mathrm{C})$ in the range between $37.96-40.41 \mathrm{~s}$ and commercial baby porridge $40.44 \mathrm{~s}$. The lowest average value of rehydration time is F2-P. Ideally, rehydrated food should be able to regain water content such as volume, shape and quality when rehydrated. Rehydration of food is highly dependent on drying conditions. High porosity greatly affects the rehydration time (Marabi and Saguy, 2004).

Water Absorption Index (WAI) or also called water absorption is an indicator of flour's ability to absorb water. Water is absorbed and bound to starch molecules which induce changes in the structure of starch molecules (Marabi and Saguy, 2004). Table 3. shows the average value of the water absorption index of powdered baby porridge formula $(\mathrm{P})$ between $3,691-3.957 \mathrm{~mL} / \mathrm{g}$, and baby porridge powder formula (C) between 3,607 $3.998 \mathrm{~mL} / \mathrm{g}$ with the average value of the highest water absorption index is F1-C. The increase in WAI value was influenced by the pre-gelatination process. Pregelatination is flour that undergoes a gelatinization process by boiling/cooking and then drying, to improve the quality of flour as a ready-to-eat food. When the granules expand, especially the gelatinization period is reached, the hydroxyl groups of the starch fraction can bind to the surrounding water in greater quantities. Drying with a high temperature that requires more heat energy produces drying products that have a hollow starch component, especially pregelatinized starch, so that this fraction has a greater ability to absorb water and contribute to increasing the WAI value. In addition, water absorption in baby porridge is thought to be influenced by the protein component and crude fiber content. Water absorption is one of the characteristics of protein hydration, namely the ability of proteins to retain water in the food system (low water absorption). Protein will cover the starch particles so that water absorption is inhibited. The crude fiber content also contributes to reduced water absorption in starch granules.

Water solubility index (WSI) or also called water solubility indicates the presence of flour fraction that can be dissolved in water. Table 3 shows the average water solubility index of the baby porridge formula between $0.0303-0.0399 \mathrm{~g}$ with the highest average water solubility index value at F1 (P). The water solubility index is used as an indicator of the degradation of molecular components. The WSI value can measure the amount of soluble and released polysaccharides from the starch component (Ding et al., 2005). The WSI value is closely related to the content of amylose and amylopectin. Flour with high amylose content will have a high WSI. This is because amylose is more soluble than amylopectin. WSI value is not only influenced by starch content but also due to water-soluble components, such as protein (Pelembe et al., 2002).

Protein is a nutrient needed by the body for growth, building body structure (muscle, skin, and bone) and as a substitute for worn-out tissue. Protein is one of the macronutrients that functions as a building block, maintains cells and body tissues and helps in the metabolism of a person's immune system (Chang and Zhang, 2017). Protein has the most important value because it is very closely related to life processes. All living cells are associated with protein nutrients, therefore protein can play a role in transporting nutrients from the digestive tract through the walls of the digestive tract into the blood (Almatsier, 2009).

The increase in the weight of rats was associated with nutritional factors and protein content in the feed consumed by rats. Protein has a function for growth and transporting nutrients from the digestive tract into the blood (Asmak et al., 2020).

Rats that consumed baby porridge formula F2 with FPH substitution had the highest body weight growth, this was related to F2 formula which had a high protein digestibility value which played a role in the growth of mice. This is in line with previous research which showed that rats consuming black soybean tempeh and tempeh extract experienced higher growth than standard feed (Aminah and Yusuf, 2015). FPH also contains the amino acid leucine which increases the production of growth hormone and helps burn fat located in the deepest layers of the body (Abdullah et al., 2013).

Weight gain in the $\mathrm{P} 2$ group is also influenced by the amount of feed the treatment group occupies the highest position (FCE $=50.99 \%$ ) and the PER value of the P2 group is also higher than the other treatment groups. The PER value is calculated to describe all proteins used only for body growth. The higher the PER value, the more efficient the protein in the feed to increase the weight growth of rats (Muchtadi, 2010).

The nutritional value of protein can be assessed based on the level and protein digestibility (Putri et al., 2020). Protein digestibility is the ability of a protein to be hydrolyzed into amino acids by digestive enzymes (proteases) which will then be absorbed and used by the body (Muchtadi, 2010).

The digestibility value of protein is influenced by the processing process and the reaction between protein and other compounds in the food (Maligan, 2013). The F2 formula with ingredients FPH, mung bean flour and skim 
milk, has the highest digestibility among other formulas and also commercial baby porridge. The high protein digestibility value in the F2 formula $(90.91 \%)$ can be caused by the presence of FPH which has high protein content, complete amino acids, and high protein digestibility (Nurhayati et al., 2013). This is also evidenced by the protein digestibility value of FPH which is the highest (93.61\%).

Food protein that has undergone partial digestion will be further digested by enzymes from the pancreas consisting of trypsinogen, chymotrypsinogen, carboxypeptidase, and endopeptidase. (Whitcomb and Lowe, 2007). Trypsinogen and endopeptidase are activated by enterokinase in the small intestine. This occurs as a result of chyme stimulation of the small intestinal mucosa. Pancreatic enzymes that break down proteins from polypeptides form into shorter peptides, including tripeptides, dipeptides, and some into amino acids. The small intestinal mucosa also secretes protease enzymes that hydrolyze peptide bonds (Almatsier, 2009).

Protein food in the small intestine will be completely digested into amino acids and then absorbed through the epithelial cells of the intestinal wall. Absorption takes place through passive diffusion as well as sodiumdependent active transport mechanisms. Amino acids that are absorbed will then enter the blood circulation through the portal vein and be carried to the liver. Some amino acids are used by the liver and others through the blood circulation are carried to tissue cells (Kiela and Ghishan, 2017). In addition to absorbing amino acids from food, the intestinal mucosa also absorbs quite a lot of endogenous amino acids ( $\pm 80 \mathrm{~g} /$ day $)$, which are derived from secretions into the small intestine and exfoliated cells from the mucosal surface.

The addition of endogenous amino acids causes the composition of amino acids to become more balanced which increases absorption. This is in line with previous research (Rubio and Clemente, 2009) that is, after $2 \mathrm{hrs}$ of incubation, the transport values of all amino acids in isolated chickpea protein (ICP) and isolated lupine protein (ILP) were lower $(\mathrm{p}<0.01)$ except for glutamate, valine and isoleucine compared to casein or lactalbumin meaning amino acids from isolated chickpea protein. ICP and ILP are absorbed more slowly than animal protein, a nutritional value lower legume protein compared to lactalbumin or casein (Rubio and Clemente, 2009).

Protein absorption was analyzed five times for $2 \mathrm{hrs}$ at $0,30,60,90$, and 120 mins. Analysis of protein absorption aims to determine how long the feed consumed will be absorbed by the body. The highest protein absorption value was in the 60th minute with an average value of $17.92 \%(\mathrm{P} 2)$. When the process of absorption of protein in the body takes time so that the protein in food can be fully absorbed by the body. The absorption of baby porridge formula is also higher than commercial baby porridge. Protein food in the small intestine will be completely digested into amino acids and then absorbed through the epithelial cells of the intestinal wall. Absorption takes place through passive diffusion as well as sodium-dependent active transport mechanisms. Amino acids that are absorbed will then enter the blood circulation through the portal vein and carried to the liver (Barasi, 2009).

\section{Conclusion}

Assessment of acceptability test/organoleptic FPHenriched HCPF includes the appearance of color, aroma, and texture acceptable to the panelists. Compared to commercial products, the FPH-enriched instant baby porridge product as a result of this study has a higher bulk density than commercial products. The highest WAI is in F1-C, the highest WSI is F1-P and the Rehydration test with the lowest time is at F2-P. FPH-enriched complementary feeding with various protein contents tested was proven to significantly increase growth, the best result was found in the P2 treatment group FPHenriched complementary feeding was proven to significantly increase the FCE value, which was the best result found in the P2 treatment group. FPH-enriched complementary feeding was proven to significantly increase the PER value, the best was found in the P2 treatment group. The F2 formula has a higher protein digestibility (90.91\%) when compared to commercial baby porridge products (46.3\%). FPH-enriched complementary feeding was significantly proven to have the best protein absorption in the P2 treatment group. FPH-enriched complementary feeding shows the best result with various tested protein contents. It was significantly proven to have the best protein absorption in the P2 treatment group. The highest average absorption was obtained at 60 mins for all groups of rats that were intervened. The highest absorption was found in the group of rats treated with 3 (P2) (best formula 2), followed by P3 (formula 3), and P1 (formula 1).

\section{Conflict of interest}

The authors declare no conflict of interest.

\section{Acknowledgements}

The author thanks the National Innovation System Research Incentive (INSINAS) as a source of research funding contract no 5/INS-2/PPK/E-4/2018 Prof. Dr Ekowati Chasanah. 


\section{References}

Abdullah, A., Nurjanah, T. and Yusefi, V. (2013). Profil Asam Amino Dan Asam Lemak Kerang Bulu (Anadara antiquata) Profile of Amino Acid and Fatty Acid of Hairy Cockle (Anadara antiquata). Jurnal Pengolahan Hasil Perikanan Indonesia, 16 (2), 169-167. [In Bahasa Indonesia].

Aboud, F.E., Shafique, S. and Akhter, S. (2009). A responsive feeding intervention increases children's self-feeding and maternal responsiveness but not weight gain. Journal of Nutrition, 139(9), 17381743. https://doi.org/10.3945/jn.109.104885

Almatsier, S. (2009). Basic Principles of Nutrition. Jakarta, Indonesia: PT. Gramedia Pustaka Utama.

Aminah, S. and Yusuf, M. (2015). Efisiensi Pakan, Berat Badan Dan Panjang Tulang Tikus Yang Mengkonsumsi Kejale Selama 6 Minggu, presented at the $2^{\text {nd }}$ University Research Coloquium 2015, p. 451-459. Indonesia: Universitas Muhammadiyah Semarang. [In Bahasa Indonesia].

Anwar, F., Latif, S., Przybylski, R., Sultana, B. and Ashraf, M. (2007). Chemical composition and antioxidant activity of seeds of different cultivars of mungbean. Journal of Food Science, 72(7), 503510.

3841.2007.00462.x

Arifianti, A., Anandito, R.B.K., Affandi, R.D. and Parnanto, N.H.R. (2012). Karakterisasi Bubur Bayi Instan Berbahan Dasar Tepung Millet (Panicum sp) dan Tepung Beras Hitam (Oryza sativa L. Japonica) dengan flavor alami Pisang Ambon (Musa paradisiaca var. sapientum). Jurnal Teknosains Pangan, 1(1), 95-104. [In Bahasa Indonesia].

Asmak, N., Kusmiyati-Tjahjono, D.K., Chasanah, E., Fawzya, Y.N., Martosuyono, P., Nuryanto and Afifah, D.N. (2020). The effect of fish protein hydrolysate (FPH) substitution complementary feeding formula on the albumin levels of sprague dawley rat. Food Research, 4(Suppl. 3), 18-23. https://doi.org/10.26656/fr.2017.4(S3).S07

Aubourg, S.P. (2001). Fluorescence study of the prooxidant effect of free fatty acids on marine lipids. Journal of the Science of Food and Agriculture, 81 (4), 385-390. https://doi.org/10.1002/1097-0010 (200103)81:4<385::AID-JSFA821>3.0.CO;2-X

Badan Pengawas Obat dan Makanan. (2021). Pedoman Cara Ritel Pangan yang Baik. (2012). Indonesia: Badan Pengawas Obat dan Makanan. [In Bahasa Indonesia].

Balitbang Kemenkes RI. (2013). Riset Kesehatan Dasar. Indonesia: Balitbang Kemenkes RI. [In Bahasa Indonesia].
Barasi, M.E. (2009). At a Glance Ilmu Gizi. Jakarta, Indonesia: Erlangga.

Bloem, M.W., de Pee, S., Hop, L.T., Khan, N.C., Laillou, A., Minarto, Wasantwisut, E. (2013). Key strategies to further reduce stunting in Southeast Asia: lessons from the ASEAN countries workshop. Food and Nutrition Bulletin, 34(Suppl. 2), 8-16. https://doi.org/10.1177/15648265130342s103

Chang, S.K.C. and Zhang, Y. (2017). Protein Analysis. In Nielsen, S.S. (Ed.) Food Analysis, p. 315-331. Switzerland: Springer Nature. https:// doi.org/10.1007/978-3-319-45776-5

Chasanah, E., Susilowati, R., Yuwono, P., Zilda, D.S. and Fawzya, Y.N. (2019). Amino acid profile of biologically processed fish protein hydrolysate (FPH) using local enzyme to combat stunting Amino acid profile of biologically processed fish protein hydrolysate $(\mathrm{FPH})$ using local enzyme to combat stunting. IOP Conference Series: Earth and Enviromental Science, 278, 012013. https:// doi.org/10.1088/1755-1315/278/1/012013

de Onis, M. and Branca, F. (2016). Childhood stunting: A global perspective. Maternal and Child Nutrition, 12(S1), 12-26. https://doi.org/10.1111/mcn.12231

Dewey, K.G. and Adu-Afarwuah, S. (2008). Systematic review of the efficacy and effectiveness of complementary feeding interventions in developing countries. Maternal and Child Nutrition, 4(Suppl. 1), 24-85. 8709.2007.00124.x

https://doi.org/10.1111/j.1740-

Ding, Q., Ainsworth, P., Tucker, G. and Marson, H. (2005). The effect of extrusion conditions on the physicochemical properties and sensory characteristics of rice-based expanded snacks. Journal of Food Engineering, 66(3), 283-289. https://doi.org/10.1016/j.jfoodeng.2004.03.019

Farahita, Y., Junianto and Kurniawati, N. (2012). Karakteristik Kimia Caviar Nilem dalam Perendaman Campuran Larutan Asam Asetat dengan Larutan Garam Selama Penyimpanan Suhu Dingin (5-10 oC). Jurnal Perikanan Dan Kelautan, 3(4), 165-170. [In Bahasa Indonesia].

Gilang, R., Affandi, D.R., Ishartani, D., Teknologi, J., Pertanian, H., Pertanian, F. and Maret, U.S. (2013). Karakteristik Fisik dan Kimia Tepung Koro Pedang (Canavalia ensiformis) Dengan Variasi Perlakuan Pendahuluan. Journal Teknosains Pangan, 2(3), 3442. [In Bahasa Indonesia].

Hoseney, R.C. (1984). Chemical Changes in Carbohydrates Produced by Thermal Processing. Journal of Chemical Education, 61(4), 308-312. https://doi.org/10.1021/ed061p308 
Kiela, P.R. and Ghishan, F.K. (2017). Physiology of Intestinal Absorption and Secretion. Best Practice and Research: Clinical Gastroenterology, 30(2), 145 -159 . https://doi.org/10.1016/ j.bpg.2016.02.007.Physiology

Liang, N., Chen, X. and Kitts, D.D. (2018). Journal of Nutrition and Food Sciences Sugar Loss Attributed to Non-Enzymatic Browning Corresponds to Reduce Calories Recovered in Low-Molecular-Weight Fraction. Journal of Nutrition and Food Sciences, 8 (2), 674. https://doi.org/10.4172/2155-9600.1000674

Lim, J. (2011). Hedonic scaling: A review of methods and theory. Food Quality and Preference, 22(8), 733 -747. https://doi.org/10.1016/j.foodqual.2011.05.008

Maligan, J.M. (2013). Nutrition and Food Evaluation: Protein. Indonesia: Universitas Brawijaya.

Marabi, A. and Saguy, I.S. (2004). Effect of porosity on rehydration of dry food particulates. Journal of Science of Food and Agriculture, 84(10), 11051110. https://doi.org/10.1002/jsfa.1793

Martosuyono, P., Fawzya, Y.N., Patantis, G. and Sugiyono. (2019). Enzymatic production of fish protein hydrolysates in a pilot plant scale. Squalene Bulletin of Marine and Fisheries Postharvest and Biotechnology, 14(2), 85-92. https:// doi.org/10.15578/squalen.v14i2.398

Muchtadi, D. (2010). Teknik Evaluasi Nilai Gizi Protein. Bandung, Indonesia: Alfabeta.

Nurhayati, T., Nurjanah and Sanapi, C.H. (2013). Karakterisasi Hidrolisat Protein Ikan Lele Dumbo (Clarias Gariepinus). Jurnal Pengolahan Hasil Perikanan Indonesia, 16, 207 - 214

Paudel, R., Pradhan, B., Wagle, R.R., Pahari, D.P. and Onta, S R. (2012). Risk factors for stunting among children: A community based case control study in Nepal. Kathmandu University Medical Journal, 10 (39), 18-24. https://doi.org/10.3126/ kumj.v10i3.8012

Pelembe, L.A.M., Erasmus, C. and Taylor, J.R.N. (2002). Development of a Protein-rich Composite Sorghum - Cowpea Instant Porridge by Extrusion Cooking Process. Food Science and Technology, 35 (2), 120-127. https://doi.org/10.1006/fstl.2001.0812

Putri, A. R., Anwar, A., Chasanah, E., Fawzya, Y.N., Martosuyono, P., Nuryanto and Afifah, D.N. (2020). Analysis of iron, calcium and zinc contents in formulated fish protein hydrolyzate (FPH) complementary feeding instant powder. Food Research, 4(Suppl. 3), 63-66. https:// doi.org/10.26656/fr.2017.4(S3).S09

Rubio, L.A. and Clemente, A. (2009). In vivo (rat) and in vitro (Caco-2 cells) absorption of amino acids from legume as compared to lactalbumin or casein. Archives of Animal Nutrition, 63(5), 413-426. https://doi.org/10.1080/17450390903169237

Sharif, M.K., Butt, M.S., Sharif, H.R. and Nasir, M. (2017). Sensory Evaluation and Consumer Acceptability. In Zahoor, T. and Butt, M.S. (Ed.) Handbook of Food Science and Technology. Vol. 1, p. 362 - 386. Pakistan: University of Agriculture,

Shevkani, K., Singh, N., Kaur, A. and Rana, J.C. (2015). Structural and functional characterization of kidney bean and field pea protein isolates: A comparative study. Food Hydrocolloids, 43, 679-689. https:// doi.org/10.1016/j.foodhyd.2014.07.024

Singh-ackbarali, D. and Maharaj, R. (2014). Sensory Evaluation as a Tool in Determining Acceptability of Innovative Products Developed by Undergraduate Students in Food Science and Technology at The University of Trinidad and Tobago. Journal of Curriculum and Teaching, 3(1), 10-27. https:// doi.org/10.5430/jct.v3n1p10

Whitcomb, D.C. and Lowe, M.E. (2007). Human Pancreatic Digestive Enzymes. Digestive Diseases and Sciences, 52, 1 - 17. https://doi.org/10.1007/ s10620-006-9589-z

Wongpornchai, S., Dumri, K., Jongkaewwattana, S. and Siri, B. (2004). Food Chemistry Effects of drying methods and storage time on the aroma and milling quality of rice (Oryza sativa L .) cv . Khao Dawk Mali 105. Food Chemistry, 87(3), 407-414. https:// doi.org/10.1016/j.foodchem.2003.12.014

World Health Organization. (2010). Interpretation Guide. Nutrition Landscape Information System (NLIS) Country Profile, 50. Retrieved from www.who.int/nutrition

Yudi and Parakkasi, A. (2005). Pengaruh Level Protein, Vitamin A dan Vitamin E terhadap Pertambahan Bobot Badan dan Beberapa Fungsi Reproduksi Tikus Putih (Rattus novergicus). Journal of Animal Science and Technology, 28, 63-69. Media Peternakan, 28 (2), 63-69. [In Bahasa Indonesia]. 